DOI: $10.19195 / 2084-5065.52 .7$

\title{
A few remarks on state compensation to victims of crime
}

\author{
ANNA MUSZYŃSKA \\ ORCID: 0000-0003-2008-382X \\ Department of Material Criminal Law \\ Faculty of Law, Administration and Economics \\ University of Wrocław
}

Compensation for the damage caused by an offence is received primarily when the aggrieved party pursues a claim against the offender. Legal regulations relating to the protection of the aggrieved party's interests from the consequences of the offence contain a wide scope of measures which are compensatory in nature. These measures are provided for within the field of substantive criminal law. The aggrieved party may also choose the civil-law path to seek damages and recompense.

Obtaining compensation from the offender by individually seeking the redress of damage, whether in criminal or civil proceedings, frequently proves to be impossible. There are many different causes of this situation, such as the fact that the offender has not been apprehended or other reasons which prevent the enforcement of damages from a perpetrator who has been apprehended. In such circumstances the question arises whether it is possible to obtain state compensation. That is, to obtain funds from a public fund created to satisfy the victims' claims in relation to redress of damage caused by an offence.

The problem of state's shared responsibility for the consequences of offences and its engagement in material assistance to the victims is revived each time an attempt is made to verify the legal measures regarding these 
issues under the Polish legal system. ${ }^{1}$ A number of critical remarks are still being made in the discussions. ${ }^{2}$ They concern issues such as determination of entities eligible for compensation, its scope, information and application review procedures and finally the nature of compensation and source of financing. An assessment of the current legal solutions is crucial in the context of major problems arising and amendments needed in this area.

As is known, in Poland, a more comprehensive system of assistance to victims of offences was established with the introduction of the Act on State Compensation to Victims of Certain Intentional Offences of 7 July 2005. ${ }^{3}$ International legal instruments regulating the status of the victim of an offence had a considerable impact on the development of the compensation fund concept. It should be recalled that the rules on granting assistance to victims of a crime or offence have been developed much earlier within the structures of the United Nations, Council of Europe and European Union. These rules primarily stressed the need to establish judicial mechanisms which would: enable the victims to obtain compensation for harm suffered, permit restitution as an alternative criminal sanction, provide financial state compensation to the victims who have suffered grievous or other bodily harm as well as to the victims' families in the event of the victim's death. ${ }^{4}$ Among the most notable international instruments the following should be enumerated: UN Declaration of Basic Principles of Justice for Victims of Crime and Abuse of Power 1985, European Convention on the Compensation of Victims of Violent Crimes 1983, Council of Europe Recommendation No. R (85) 11 on the Position of the Victim in the Framework of Criminal Law and Procedure and Council of Europe Recommendation No. R (87) 21 on Assistance to Victims and the Prevention of Victimisation. In the European Union, by means of Council Directive

1 See: R. Giętkowski, "Kilka uwag na temat koncepcji publicznego funduszu kompensacyjnego dla ofiar przestępstw," Pal. 2006, no. 3-4, pp. 25-34.

2 E. Bieńkowska, "Prawo ofiary do kompensaty od państwa po zmianach z dnia 5 sierpnia 2015 r.," Prok. i Pr. 2016, no. 7-8, pp. 166-167; K. Dudka, "Wybrane aspekty państwowej kompensaty dla ofiar przestępstw," [in:] Dochodzenie roszczeń cywilnych a proces karny, ed. A. Lach, Warszawa 2018, p. 256 et seq.

3 Dz.U. (Journal of Laws) no. 169, item 1415.

4 E. Bieńkowska, L. Mazowiecka, Ofiara przestępstwa w dokumentach międzynarodowych, Warszawa 2009, p. 71 et seq. 
2004/80/EC of 29 April 2004 relating to compensation to crime victims, ${ }^{5}$ Member States were obliged to set up a system of public compensation to victims of crime. Upon implementation of the above-mentioned directive, the Act of 7 July 2005 has been introduced into the Polish legal system. This Act established the principles and mode for granting compensation and the conditions for cooperation of the authorities of the Republic of Poland with the authorities of other EU Member States competent in matters concerning compensation. In general, it can be observed that the statute adopted only minimum standards contained in the EU directive and has been criticised from the moment it became effective. First of all, it has been noted that contrary to the requirements laid down in the directive, the Polish compensation system started operating on 21 September 2005, although it was meant to be launched on 1 July 2005. Moreover, critics have pointed out normative deficiencies uncovered in application of the statute, such as its narrow personal scope, exclusion from compensation when guilt could not be attributed to the perpetrator or no separation of provisions on national and cross-border compensation. ${ }^{6}$ Some of the deficiencies were remedied by the Act on Amendment to the Act on State Compensation to Victims of Certain Intentional Offences of 11 April 2008 , pursuant to which the provisions on compensation apply to the offences committed after 30 June 2005 and the two-year period for the expiry of the right to seek compensation based on such applications should be counted from the moment the amendment came into force. ${ }^{7}$

Not all normative deficiencies pointed out in the discussions on state compensation regulations were remedied by the 2008 amendment. Unfortunately, the consecutive amendment introduced by the Act on the Amendment to the Act on State Compensation to Victims of Certain Intentional Offences of 3 April $2009^{8}$ also has not led to changes on a wider

5 OJ L 261 of 6 August 2004.

${ }^{6}$ E. Bieńkowska, op. cit., pp. 149-150; see also M. Mazur, "Kompensata dla ofiar przestępstw. Co sprawdzone, a co wymaga poprawy?,” Na Wokandzie 2011, no. 10, p. 2 et seq.; L. Mazowiecka, Państwowa kompensata dla ofiar przestępstw, Warszawa 2012, p. 200 et seq.

7 Dz.U. (Journal of Laws) no. 96, item 608, the statute came into force on 20 June 2008.

8 Dz.U. (Journal of Laws) no. 79, item 665. 
scale. ${ }^{9}$ As part of the 2009 amendment the term "intentional" was deleted and the statute received the changed title of the Act on State Compensation to Victims of Certain Offences. The possibility of obtaining reimbursement for the costs of rehabilitation was added. In addition, the prosecutor was authorised to file a compensation application in favour of the victims of crime or their closest relatives. Another amendment introduced was questionable. It changed the territorial jurisdiction of the court reviewing the compensation application: from the place where the offence was committed to the place where the applicants have their habitual residence. None of these amendments contributed to the more frequent application of the statute's provisions in practice, ${ }^{10}$ or to a positive assessment of the said regulation. ${ }^{11}$ To the contrary, the need for a prompt amendment was stressed.

The third modification, the Act on the Amendment of an Act on State Compensation to Victims of Certain Offences, statute- Code of Civil Procedure and the Act on Costs in Civil Cases of 5 August 2015, ${ }^{12}$ has finally introduced changes which have substantially improved the formerly existing state compensation regulations. Firstly, it needs to be underlined that once again the title has been modified. The term "offence" has been replaced with the term 'prohibited act' and the current title of the statute is an Act on State Compensation to Victims of Certain Prohibited Acts. This amendment should be viewed in a broader context, since it has removed the drawback of the previously existing mechanism which only permitted to file for compensation when an offence was committed. The previously existing formulation excluded the possibility to file a compen-

9 See: E. Bieńkowska, "Państwowa kompensata dla ofiar w Polsce," Prok. i Pr. 2008, no. 5, p. 51 et seq.

10 M. Kolendowska-Matejczuk, "Kompensata państwowa dla ofiar przestępstw krytyczna analiza polskiej ustawy kompensacyjnej," RPEiS 2014, no. 4, p. 152 et seq.; see also L. Mazowiecka, "Wyniki badań nad funkcjonowaniem ustawy o kompensacie państwowej," [in:] Kompensata państwowa dla ofiar przestęsstw w Polsce. Teraźniejszość i przyszłość, ed. L. Mazowiecka, Warszawa 2013; S. Łagodziński, ’Praktyka przyznawania świadczeń na podstawie ustawy z 7.07.2005 r. o państwowej kompensacie przysługującej ofiarom niektórych przestępstw," Prawo w działaniu. Sprawy karne 9, 2011, p. 124 et seq.

11 E. Bieńkowska, L. Mazowiecka, Państwowa kompensata przysługująca ofiarom niektórych przestepstw. Komentarz, Warszawa 2011, p. 57 et seq.

12 Dz.U. (Journal of Laws) item 1587. 
sation application when the perpetrator of the prohibited act could not have been held criminally liable, e.g. due to insanity or immunity protection.

The 2015 amendment affected the catalogue of entities eligible to file a compensation application, de facto broadening this catalogue. The legislator conferred the right to obtain compensation on the victim of the offence who suffered grievous bodily harm, physical injury or damage to health lasting longer than seven days and the next of kin of the victim who died. At the same time the legislator used the criterion of citizenship. This criterion became irrelevant after the amendment, because the criterion of place of habitual residence was adopted. Pursuant to the new wording of article 4 of the Act, compensation is granted if the prohibited act was committed in the territory of the Republic of Poland against a person having permanent residence in the territory of Poland or another EU Member State. The place of permanent residence is not relevant with regard to the next of kin. In relation to the next of kin the legislator has further waived a restriction based on which such a person could only seek compensation on the grounds that at the time the offence was committed, he or she was dependent on the victim.

The amendment changed and ordered the grounds for granting compensation. Article 7 of the Act was repealed. This provision made granting of compensation dependent on whether criminal proceedings were instituted or institution of the proceedings was denied because of the occurrence of one of the exhaustingly listed negative conditions of criminal proceedings, provided for in article $17 \S 1$ (4), (5), (8), (10) and (11) of the Code of Criminal Procedure. ${ }^{13}$ The above-mentioned article 7 further provided that no compensation should be granted if the criminal proceedings which had been instituted were later discontinued on the grounds set forth in article $17 \S 1$ (1), (2), (3), (7) and (9) of the Code of Criminal Procedure, or the accused was acquitted on the grounds provided for in article 17 $\S 1$ (1) and (2) of the Code of Criminal Procedure. After the amendment, the institution or denial of institution of criminal proceedings ceased to apply as a statutory requirement. Nevertheless, this does not mean that filing for compensation is now entirely isolated from the information on the

13 Act of 6 June 1997 - Code of Criminal Procedure (Dz.U. [Journal of Laws] no. 89 , item 555 , as amended). 
criminal proceedings regarding the prohibited act. In keeping with what is prescribed by the legislator, the applicant should attach to the application, among others, a copy of notification of an offence, copies of relevant rulings issued in criminal proceedings and other documents confirming the information contained in the application.

Compensation is granted both when the perpetrator has been convicted and when the proceedings were discontinued. In the amending act it has been clearly stated that not every discontinuance of the proceedings gives the right to obtain compensation. For obvious reasons, the conditions regarding criminal responsibility of the perpetrator set forth in article 17 $\S 1$ (1) and (2) of the Code of Criminal Procedure, exclude the right to compensation. These conditions include the following: the act does not have the features of a prohibited act, the act has not been committed or there are insufficient grounds to suspect that the act was committed. What is more, in article 7a of the Act, which regulates the grounds for refusal of compensation, additional circumstances were determined, that is if the victim has contributed to the commitment of the prohibited act (although it is also possible to lower the amount of compensation proportionately to the contribution), if the victim co-perpetrated the prohibited act which results in the victim's right to compensation or if the victim consented to the risk of suffering the consequences of the prohibited act.

Further normative changes were reflected in the specification of formal requirements which the compensation application should meet. In this respect, certain simplifications were made to facilitate the preparation of an application by the eligible person. Importantly, the deadline for submitting the application has been extended. Under the legislation previously in force, it was two years from the day when the offence was committed. In the new legislation it is the period of three years counted from the day on which the effects of the prohibited act came to light, however the application cannot be filed later than within five years from the day on which the act was committed. This amended regulation addressed the criticism voiced with regard to practical application of the compensatory statute. Critics argued that the previous deadline was insufficient for the applicants.

The change in the amount of compensation was of particular importance to eligible persons. Pursuant to the former regulation contained in article 6 of the Act, the maximum possible amount of compensation was 
set at PLN 12,000. After the amendment, the amount of compensation cannot exceed PLN 25,000, and in the event of death of the victim PLN 60,000. This allows us to assess the amount of compensation more properly, given the results of the prohibited act, which are mentioned in the statute. Furthermore, a new provision was added by the amending act. Pursuant to this provision, if in the case for granting compensation the court decides that it is impossible or extremely difficult to prove the amount claimed, the court may, within the limits set forth in the statute, award such an amount as it deems appropriate, taking into consideration all the facts of the case. The adoption of the provision on the court's discretion with regard to the amount of compensation when evidentiary difficulties arise, should be perceived as an additional emphasis placed on the already existing possibility. This is especially so, given the fact that a compensation application is reviewed in accordance with the provisions of the Code of Civil Procedure, ${ }^{14}$ and the deciding authority could use such discretion from the moment the Act became effective.

While on the subject of pragmatic amendments, it should be stressed that persons seeking compensation are exempted from court costs. Waiving a fixed application fee that needs to be paid by the eligible persons should also be considered. The concern of the legislator that the fee safeguards the judicial system from an increased number of groundless applications seems to be unfounded.

The district court with jurisdiction over the place where the eligible person habitually resides has been established as an authority competent to decide upon applications for compensation. This type of jurisdiction has already been established by the 2009 amendment in order to facilitate satisfaction of claims by victims of prohibited acts. Thanks to this mechanism the victim does not need to file a claim to the court having jurisdiction over the place where the offence was committed, which is frequently located far away from the victim's place of residence. Such a facilitation is not entirely convincing, especially in light of the fact that the eligible person attaches to the application documents which were produced during preparatory proceedings conducted in the jurisdiction where the of-

14 Act of 17 November 1964 - Code of Civil Procedure (Dz.U. [Journal of Laws] of 2014, item 101, as amended). 
fence was committed. Under the amendment the authority competent to decide in cross-border cases was also established. Pursuant to the current wording of article 8 (2) of the statute, if an eligible person has his or her habitual place of residence in the territory of another EU Member State, an authority competent to decide upon granting compensation is the court in whose district the prohibited act was committed. If it is not possible to establish territorial jurisdiction of the court in the mode set forth in this provision, the deciding authority shall be the court having jurisdiction over the Śródmieście district in the capital city of Warsaw.

The legislator decided that cases for compensation will be heard in non-contentious civil proceedings; at the same time it was stressed that the participants of the proceedings are solely the eligible person and the prosecutor. Such normative construction resulted from previous doubts concerning the offender's participation in the proceedings. Lack of express limitation in the previous legislative framework provoked arguments about who is eligible to be the participant of compensatory proceedings. Moreover, in practice, non-contentious civil proceedings were frequently transformed into contentious proceedings.

The amendment rightly modified the regulation on the assisting authority. Before the amendment came into force, an assisting authority competent in cases of obtaining compensation by the victims of the prohibited act was the regional prosecutor having jurisdiction over the place where the eligible person resided or habitually resided. This impeded victims' access to information on the possibilities and conditions for seeking compensation. This is particularly so, because relevant information was in the possession of the prosecutor who conducted preparatory proceedings concerning the prohibited act. Pursuant to the amending act, the prosecutor conducting preparatory proceedings was designated as an assisting authority competent in cases of obtaining compensation by a victim of a prohibited act committed on the territory of the Republic of Poland. It has been explicitly set forth in article 10 (2) of the Act that the tasks of the assisting authority comprise providing the applicant with information on the possibilities and conditions for compensation, as well as a template of a compensation application form and general assistance and advice on how the form should be filled in. Thus, another proposal put forward in the literature was adopted in the amended regulation, namely, the suggestion to 
facilitate the process of obtaining compensation. Nevertheless, it should be stressed that providing the victims with information concerning compensation is governed not only by the above-mentioned regulation, but should be viewed in a broader context of the activities of victim support services. ${ }^{15}$

Focusing on the prosecutor as an assisting authority, attention should also be drawn to other important functions delegated to the prosecutors under the compensation act. These functions were shaped differently by consecutive amending acts. Besides the already mentioned function of the assisting and informing authority, the prosecutor is also an entity entitled to: file a compensation application (article $8(4)$ ), be a participant of the compensatory proceedings (article $8(6)$ ), exercise the right to recourse (article 14), and bring action for repayment of compensation obtained in violation of the law (article 13). In analysing the content of article 8 of the Act, it should be assumed that the prosecutor entitled to file a compensation application as well as the participant of the proceedings for compensation, is the prosecutor who has the same territorial jurisdiction as the deciding authority, that is having jurisdiction over the eligible person's habitual place of residence. It seems that the same type of jurisdiction applies also to a recourse claim against the perpetrator. On the other hand, pursuant to article 13 (2), a claim for the repayment of the compensation granted to a person in violation of the provisions of the Act is filed by the prosecutor conducting preparatory proceedings in the case concerning the prohibited act. Prior to filing the claim the prosecutor requests this person to repay the compensation within 30 days of the receipt of the notification. This state of affairs shows a lack of consistency in regulating and assigning jurisdiction to each of the prosecutor's roles. Granting the right to file a compensation application to the prosecutor who provides the eligible person with information and assistance on seeking compensation, that is the prosecutor conducting preparatory proceedings, would be a more rational solution. This prosecutor is entitled to file a claim for the repayment of compensation and should also be entitled to seek recourse against the perpetrator. The current legislative framework creates a mix of different jurisdictions that is not very transparent. This definitely does not facilitate adequate enforcement of the provisions.

15 E. Bieńkowska, Prawo ofiary do kompensaty..., pp. 161-162. 
The compensation regulated by the 2005 Act applies only to lost earnings or other means of subsistence, medical expenses or funeral expenses resulting from the commitment of the prohibited act causing death or grievous or other bodily harm, or an impairment to health lasting longer than seven days. It does not constitute compensation for the consequences of an offence as is the case in the area of civil law and criminal law. Furthermore, provision of article 5 of the Act provides for the principle of subsidiarity, according to which, compensation is granted only if and in such an amount as the eligible person cannot receive coverage for lost earnings or other means of subsistence or expenses from the perpetrator of the prohibited act, the insurance policy or social security resources, irrespective of whether the perpetrator has been detected. As a result of the amendment, the phrase "from any other source or on any other account" was removed from article 5 of the Act. This phrase additionally restricted the possibility to receive coverage for lost earnings or other means of subsistence and created doubts concerning its interpretation and scope.

To summarise these amendments listed above, it should be concluded that the solutions which were adopted in order to fulfil international obligations are partly consistent with the expectations voiced by commentators. Nevertheless, these solutions still contain subject-matter related restrictions, which secure the financial interests of the victim of an offence only to a certain extent. At the same time, they indicate an attempt to tackle the problem of instances in which the aggrieved party, due to the reasons already mentioned, cannot obtain redress of damage.

The issue of the functioning of a public compensation fund is usually a contentious one. In other states legislative solutions concerning state compensation also encounter some difficulties. Among the most notable examples of impediments to obtaining compensation, the following are usually pointed out: highly formalised procedures for compensation application review and insufficient information provided to the victims thereon. It has also been stressed that in most cases compensation is granted to the victims of the most severe offences, under the condition that they did not receive compensation from other sources. ${ }^{16}$

16 C. Kulesza, Rola pokrzywdzonego w procesie karnym w świetle ustawodawstwa i praktyki wybranych krajów zachodnich, Białystok 1995, p. 143 et seq. 
The implementation of the idea of a state compensation fund for the victims of offences, which is surely worth endorsing, encounters a number of obstacles. These cannot be reduced only to the issue of the state's economic capacity. The absence of further specific details concerning formulated proposals leads to controversies concerning the analysed problem. Among the debatable issues are the following: the scope of compensation, source of income, procedures for reviewing compensation applications and the place of the compensation fund within the system of other benefits. It seems that the provisions of the Act on State Compensation to Victims of Certain Prohibited Acts of 7 July 2005, especially after the 2015 amendment, could serve as a starting point for specifying and ordering these issues. Widespread criticism of the first version of the compensation act has led to the correction of the majority of the normative deficiencies. Thanks to these amendments the solutions from the Act became more accessible and easier to execute for the victims of the offence.

The principles enshrined in the compensation act should be viewed in a broader context, as part of the concept whose aim is to include damage redress in the system of social security. State compensation is not meant to replace restitution and damages from the offender. It is said to have a subsidiary character, supporting the justice system. State compensation seeks to minimise the consequences that the victim of the offence has suffered. It also reflects the principle of social justice. In the current amended shape, the discussed Act gives grounds to affirm the minimum standards regarding state compensation.

\section{References}

Bieńkowska E., "Państwowa kompensata dla ofiar w Polsce,” PiP 2008, no. 5.

Bieńkowska E., "Prawo ofiary do kompensaty od państwa po zmianach z dnia 5 sierpnia 2015 r.," Prok. i Pr. 2016, no. 7-8.

Bieńkowska E., Mazowiecka L., Ofiara przestęstwa $w$ dokumentach międzynarodowych, Warszawa 2009.

Bieńkowska E., Mazowiecka L., Państwowa kompensata przystugujaca ofiarom niektórych przestepstw. Komentarz, Warszawa 2011.

Dudka K., "Wybrane aspekty państwowej kompensaty dla ofiar przestępstw," [in:] Dochodzenie roszczeń cywilnych a proces karny, ed. A. Lach, Warszawa 2018. 
Giętkowski R., "Kilka uwag na temat koncepcji publicznego funduszu kompensacyjnego dla ofiar przestępstw," Pal. 2006, no. 3-4.

Kolendowska-Matejczuk M., "Kompensata państwowa dla ofiar przestępstw — krytyczna analiza polskiej ustawy kompensacyjnej," RPEiS 2014, no. 4.

Kulesza C., Rola pokrzywdzonego w procesie karnym w świetle ustawodawstwa i praktyki wybranych krajów zachodnich, Białystok 1995.

Łagodziński S., "Praktyka przyznawania świadczeń na podstawie ustawy z 7.07.2005 r. o państwowej kompensacie przysługującej ofiarom niektórych przestępstw," Prawo w działaniu. Sprawy karne 9, 2011.

Mazowiecka L., Państwowa kompensata dla ofiar przestępstw, Warszawa 2012.

Mazowiecka L., "Wyniki badań nad funkcjonowaniem ustawy o kompensacie państwowej," [in:] Kompensata państwowa dla ofiar przestępstw w Polsce. Teraźniejszość i przyszłość, ed. L. Mazowiecka, Warszawa 2013.

Mazur M., "Kompensata dla ofiar przestępstw. Co sprawdzone, a co wymaga poprawy?" Na Wokandzie 2011, no. 10.

\section{Summary}

This article presents selected issues concerning state compensation to victims of certain offences. The fundamental principles underlying the system of assistance provided to the victims of prohibited acts were discussed, as well as amendments made thereto. Attention was primarily focused on the amendments introduced by the Amending Act of 5 August 2015. These concerned aspects such as persons eligible, scope of compensation and procedures for application review, which were analysed both by legal scholars and practitioners. It has been concluded that the amendments to a large extent eliminated the weaknesses of the previously existing regulations and thus created conditions for basic victim support.

Keywords: state compensation, victim, aggrieved party, prohibited act, redress of damage 